\title{
Experimental tests of water chemistry response to ornithological eutrophication: biological implications in Arctic freshwaters
}

\author{
Heather L. Mariash ${ }^{1}$, Milla Rautio ${ }^{2}$, Mark Mallory ${ }^{3}$, and Paul A. Smith ${ }^{1}$ \\ ${ }^{1}$ Wildlife Research Division, Environment and Climate Change Canada, Ottawa, Ontario, K1A 0H3, Canada \\ ${ }^{2}$ Centre d'études nordiques and Département des sciences fondamentales, \\ Université du Québec à Chicoutimi, Chicoutimi, Quebec, G7H 2B1, Canada \\ ${ }^{3}$ Biology Department, Acadia University, Wolfville, Nova Scotia, B4P 2R6, Canada
}

Correspondence: Heather L. Mariash (heather.mariash@gmail.com)

Received: 27 April 2019 - Discussion started: 27 May 2019

Revised: 29 October 2019 - Accepted: 7 November 2019 - Published: 10 December 2019

\begin{abstract}
Many populations of Arctic-breeding geese have increased in abundance in recent decades, and in the Canadian Arctic, snow geese (Chen caerulescens) and Ross's geese (Chen rossii) are formally considered overabundant by wildlife managers. The impacts of these overabundant geese on terrestrial habitats are well documented, and, more recently, studies have suggested impacts on freshwater ecosystems as well. The direct contribution of nutrients from goose faeces to water chemistry could have cascading effects on biological functioning, through changes in phytoplankton biovolumes and community composition. We demonstrated previously that goose faeces can enrich ponds with nutrients at a landscape scale. Here, we show experimentally that goose droppings rapidly released nitrogen and phosphorus when submerged in freshwater, increasing the dissolved nitrogen and phosphorus in the water. This resulted in both a decrease in the nitrogen:phosphorus ratio and an increase in cyanobacteria in the goose dropping treatment. In contrast, this pattern was not found when we submerged cut sedge (Carex sp.) leaves. These results demonstrate that geese act as bio-vectors, causing terrestrial nutrients to be bioavailable in freshwater systems. Collectively, the results demonstrate the direct ecological consequences of ornithological nutrient loading from hyper-abundant geese in Arctic freshwater ecosystems.
\end{abstract}

\section{Introduction}

Arctic regions are important breeding grounds for a wide range of migratory species. With 22.1 million geese, belonging to five species, breeding in the Canadian Arctic (Fox and Leafloor, 2018), along with substantial numbers of nonbreeders, geese are ubiquitous in the Arctic landscape during the summer. Goose populations have been increasing since the 1950 s, primarily due to changes in agricultural practices that have increased food availability in the southern wintering grounds but also because of increased survival from increased use of wildlife reserves and protected areas, as well as milder winters (Abraham et al., 2005).

Increases in abundance have been especially pronounced for several populations of snow geese (Chen caerulescens) and Ross's geese (Chen rossii) (Fox and Leafloor, 2018). These large and increasing populations have caused considerable change in the Arctic habitats that they use for staging, breeding, and brood-rearing (Abraham et al., 2012). Geese provide both deleterious and beneficial ecosystem services to tundra habitats (Buij et al., 2017). Geese also play a negative role, as repeated overgrazing of graminoid forage plants weakens them, and grubbing of the below-ground plant parts compromises vegetation regrowth and the stability of pond edges (Jefferies et al., 2006). However, geese also rapidly liberate nutrients in an otherwise nutrient-poor landscape. Because geese digest only a fraction of the plant material they ingest, they compensate for this with a high turnover from feeding to faeces (Cadieux et al., 2005). This nutrient enrichment of the terrestrial environment can lead to enhanced primary productivity (reviewed in Buij et al., 2017; see Gauthier 
et al., 1995). Geese predominantly graze around ponds, especially with broods and when they are moulting their flight feathers; the ponds are essential to escape predation. As a result, pond perimeters in areas used heavily by geese are notably mossy, brown, and muddy due to the heavy localized grazing. At these pond margins and indeed throughout the catchment, geese have the potential to influence freshwater ecosystems indirectly through this mobilization of nutrients.

While considerable research has outlined the effects of grazing and grubbing on terrestrial habitats, very few studies have focused on the associated freshwater habitats. Shallow freshwaters are highly connected to their catchments by a high surface area to volume ratio (Rautio et al., 2011). Thus, ponds are very susceptible to habitat changes within the catchment, from increased terrestrial organic matter flowing into the pond due to heavily grazed pond edges, through the decomposition of goose droppings, and through sediment bioturbation that brings nutrients back into suspension. Increased terrestrial organic matter leads to a more bacteria-based production rather than photosynthetic production (Ask et al., 2009). On the other hand, increased nutrients can cause shifts in trophic status and increased phytoplankton productivity, as demonstrated in nutrient addition experiments (Schindler et al., 2008) or in systems where seabirds act as bio-vectors transferring marine nutrients to ponds (Michelutti et al., 2009). Arctic-breeding geese could be acting as bio-vectors, causing an accumulation of terrestrial nutrients in ponds, but so far there is little published information on rates of nutrient loading into freshwater systems in the Arctic (Dessborn et al., 2016).

Additions of nitrogen and phosphorus in temperate waters can clearly contribute to eutrophication, resulting in pronounced shifts in community composition and ecosystem function (Pace et al., 2010; Schindler et al., 2008). While it has been demonstrated that goose droppings are a significant source of total nitrogen $(\mathrm{N})$ and phosphorus $(\mathrm{P})$ for nearby ponds (Côté et al., 2010; Mariash et al., 2018; Olson et al., 2005), only a few studies have attempted to quantify the magnitude of ornithological nutrient loading (Liu et al., 2014; Post et al., 1998) and relate increased nutrients to broader limnological affects (Van Geest et al., 2007; MacDonald et al., 2015; Unckless and Makarewicz, 2007). Birds can also act as vectors for the dispersal of plants, phytoplankton, and zooplankton when propagules are spread through their faeces (Figuerola and Green, 2002; Hessen et al., 2019). Currently, almost no measurements of these broader ecosystem-level effects exist for Arctic ponds.

Arctic ponds, typically characterized as transparent, oligotrophic waters, are increasingly represented by turbid, mesotrophic waterbodies (Wauthy et al., 2018; Wrona et al., 2016). Increasing Arctic temperatures and increased permafrost thaw play an important role in these changes (Vonk et al., 2015; Wauthy et al., 2018). However, geese are another potential vector of change in these ecosystems through direct (faeces) and indirect (bioturbation) nutrient release. Arc- tic freshwater wetlands used by geese are vital feeding and breeding grounds for many migratory bird species, including many sympatric and declining species of shorebirds (Flemming et al., 2019). Given the crucial ecological role played by freshwater wetlands in the Arctic, an understanding of gooserelated habitat change in Arctic freshwaters has been identified as a research priority by goose population managers.

To better understand how ornithological nutrient loading affects both water chemistry and biological functioning, we designed a study to (i) measure the nutrients released from submerged goose droppings, (ii) measure the concentration of dissolved nutrients in the water over time in the presence of these droppings, and (iii) measure the resultant changes in phytoplankton biovolume and community composition. We hypothesized that goose droppings would increase nutrient loading in the water, specifically total nitrogen and phosphorus and that this increase in nutrients would increase algal biovolume and change phytoplankton community composition, with a shift towards increased presence of cyanobacteria.

\section{Methods}

\subsection{Mesocosm experiment}

We measured the primary production and phytoplankton community composition response to nutrients released into the water column by submerged goose droppings and Carex using an in situ mesocosm experimental approach. In order to differentiate between nutrients released from the plant detritus and nutrients cycled through geese, we compared the nutrients released from undigested graminoid clippings, goose droppings, and pond water only treatments. The in situ mesocosm experiment was established in the wetlands of Southampton Island, Nunavut, Canada, at the East Bay longterm field station $\left(63^{\circ} 59^{\prime} \mathrm{N}, 81^{\circ} 40^{\prime} \mathrm{W}\right)$. Fresh goose droppings containing both faeces and uric acid from lesser snow geese and fresh clippings of the dominant graminoid (Carex sp.), herein simply referred to as Carex, were all collected on 8 July 2015 . The goose droppings were all less than $24 \mathrm{~h}$ old, moist and green in colour; the droppings were pooled and homogenized, while the Carex, including the bulb and blade, was clipped into $2 \mathrm{~cm}$ long pieces. We placed $10 \pm 0.05 \mathrm{~g}$ of goose droppings or $4 \pm 0.05 \mathrm{~g}$ of fresh Carex (approximately equivalent to $1.1 \mathrm{~g}$ dry mass), into plastic cups, which were filled with $200 \mathrm{~mL}$ of pond water that had been passed through a $<50 \mu \mathrm{m}$ sieve. The cups were placed in a floating wooden frame to keep each container upright and floating in the pond, in order to retain some natural turbulence (Fig. 1). The cups were covered with plastic wrap to allow light through but prevent evaporation or overfilling. The experiment was conducted for $17 \mathrm{~d}$ in the pond at ambient temperatures (average temperature in the cups $8.2^{\circ} \mathrm{C}$ ) and 


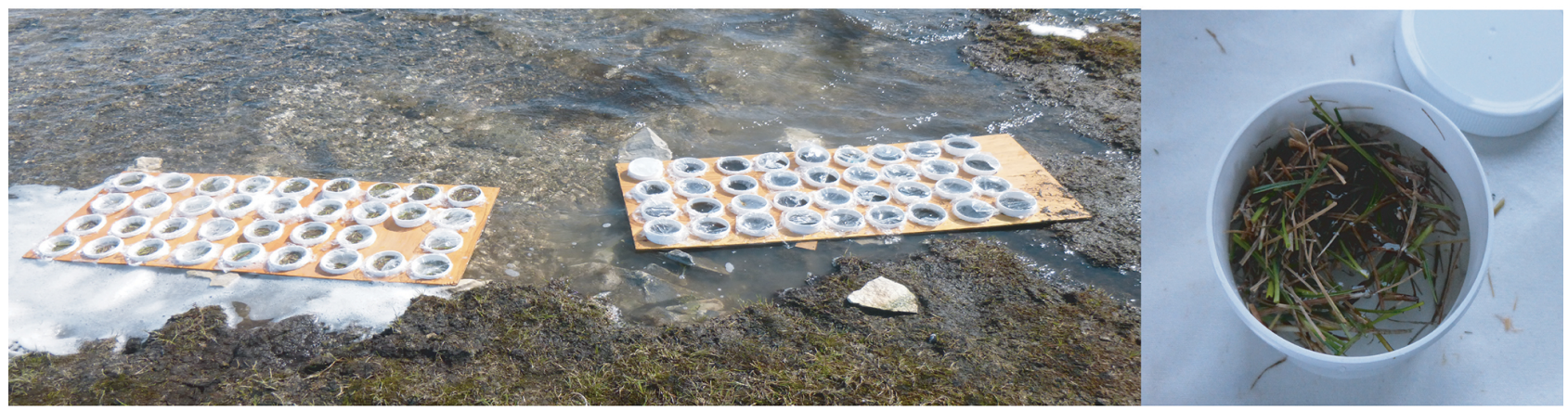

Figure 1. Mesocosm set-up in the pond. Sample cups had either fresh Carex clippings or fresh goose droppings submerged in $200 \mathrm{~mL}$ of pond water. The organic matter and the water from experimental cups were sampled throughout the $17 \mathrm{~d}$ experiment.

natural light conditions (approximately $21 \mathrm{~h}$ daylight, $3 \mathrm{~h}$ of dusk).

Treatments were goose droppings and Carex with five replicates of each treatment for each sampling day, along with control cups containing only pond water. Water parameters were sampled on days $1,3,5,10$, and 17 . On sampling days, we sampled both the overlying water and the organic matter from the five cups per treatment to measure the rate of nutrients released into the water and decomposition of the Carex and goose droppings. For nutrient samples, the water from two of the five cups from each treatment was passed through $50 \mu \mathrm{m}$ sieve and poured into prepared vials for total phosphorous ( $40 \mathrm{~mL}$ volume with $116 \mu \mathrm{L}$ of $30 \% \mathrm{H}_{2} \mathrm{SO}_{4}$ ) and total nitrogen $(24 \mathrm{~mL}$ volume with $230 \mu \mathrm{L} \mathrm{HCL})$. The water from the remaining three replicates was pooled for phytoplankton community composition $(150 \mathrm{~mL}$ amber glass bottle preserved with Lugol's iodine solution). Phytoplankton were only sampled during the first $10 \mathrm{~d}$ of the experiment, to limit the cup effect on phytoplankton community dynamics.

\subsection{Identifying an appropriate loading rate}

To compare our results to those published from elsewhere, it was necessary to establish a "faecal loading rate" with consistent units. We define nutrient loading rate within the catchment as the concentration of nitrogen and phosphorus measured from goose droppings, scaled up using rates of defecation and the density of geese per square kilometre reported for each site used in our comparisons, for a final unit of kilogram of nutrients per square kilometre per day. The loading rate for the region in which our study took place, Southampton Island, was calculated based on nutrient concentrations from the goose droppings used in the experiment, combined with a conservative estimate of faecal production based on weight and defecation rate per day (Unckless and Makarewicz, 2007) and the average density of geese breeding in Southampton Island goose colonies (Kerbes et al., 2014). We view this estimate as conservative because non-breeding geese are numerous across Southampton Island (perhaps outnumbering breeding geese), and goslings make a substantial contribution to dropping densities. Both Kitchell et al. (1999) and Olsen et al. (2005) used the daily excretion rate for $\mathrm{N}$ and $\mathrm{P}$ as reported in Post et al. (1998). For these studies, values for Table 3 used the minimum levels reported in Post et al. (1998), which were $0.001 \mathrm{~kg} \mathrm{~N} \mathrm{~d}^{-1}$ and $0.0002 \mathrm{~kg} \mathrm{Pd}^{-1}$ per goose.

\subsection{Laboratory analysis}

The particulate organic matter, goose droppings or Carex, from each cup was frozen in the field and later freeze-dried and weighed, ground, then subsampled for carbon, nitrogen, and phosphorus content. Carbon and nitrogen content were analyzed at the University of Ottawa's G.G. Hatch Isotope Laboratory, using an elemental analyzer (Elementar Isotope Cube, Germany), from samples (Carex $2.5 \pm 0.4 \mathrm{mg}$; goose droppings $4.5 \pm 0.5 \mathrm{mg}$ ) and standards that were weighed into tin capsules and loaded into the elemental analyzer. The phosphorus from the solid samples was first processed by dissolving $0.1 \mathrm{~g}$ of each sample in $5 \mathrm{~mL}$ of concentrated $\mathrm{HNO}_{3}$ for $1 \mathrm{~h}$ at $95^{\circ} \mathrm{C}$, with an additional $1 \mathrm{~mL}$ of $\mathrm{H}_{2} \mathrm{O}_{2} 30 \%$ added to each sample then incubated for another $2 \mathrm{~h}$ at $95^{\circ} \mathrm{C}$. Ultra-pure water was added to complete the sample volume of $50 \mathrm{~mL}$. These samples were then analyzed by inductively coupled plasma atomic emission spectroscopy (ICP-AES: Varian Vista AX, Palo Alto, California, USA). The amounts of $\mathrm{C}, \mathrm{N}$, and $\mathrm{P}$ are expressed relative to the initial amounts of nutrients (\%; Table 1$)$. For the water samples, total dissolved nitrogen (TN) and total phosphorous (TP) were analyzed using catalytic combustion with a Shimadzu VCPH (Kyoto, Japan), including three blanks of ultra-pure water, at the Institut National de la Recherche Scientifique Centre Eau Terre Environment (INRS, Québec, Canada).

For the comparison of faecal loading rate and the subsequent effects on water chemistry at a landscape scale, we report previously unpublished chlorophyll $a$ values from a large-scale survey of lakes across Southampton Island (for sampling details, see Mariash et al., 2018; Table 3). Water samples from these lakes were filtered onto $\mathrm{GF} / \mathrm{F}$ fil- 
Table 1. Initial composition of Carex sp. leaves and goose droppings, and the pond water used in the experiment.

\begin{tabular}{|c|c|c|c|c|c|c|}
\hline \multirow[b]{2}{*}{ Material } & \multicolumn{2}{|c|}{ Carex clippings } & \multicolumn{2}{|c|}{ Goose droppings } & \multicolumn{2}{|c|}{ Pond water } \\
\hline & Mean \% & SD & Mean $\%$ & SD & Mean $\mathrm{mgL}^{-1}$ & SD \\
\hline Percent water ${ }^{\mathrm{a}}$ & 71.7 & 0.0 & 87.9 & 0.0 & & \\
\hline Carbon & 46.6 & 0.4 & 43.6 & 0.3 & & \\
\hline Nitrogen & 1.8 & 0.4 & 4.0 & 0.3 & 0.13 & 0.0 \\
\hline Phosphorus & 0.1 & 0.4 & 0.4 & 0.1 & 0.002 & 0.0 \\
\hline
\end{tabular}

a Percent water is calculated from wet weight versus dry weight, while the other parameters are calculated as a percentage of dry weight (DW). Solid material had five replicates, while water chemistry assays were run in duplicates.

ters (in duplicates), frozen at $-80^{\circ} \mathrm{C}$, and later analyzed using a Cary Eclipse fluorescence spectrophotometer (Aglilent, Santa Clara, USA) using standardized extraction methods and calculations (Holm-Hansen and Riemann, 1978; Jeffrey et al., 1997).

\subsection{Phytoplankton biovolumes and community composition}

Phytoplankton biovolumes, volume of cells per volume of water, and community composition were measured from Lugol-preserved samples using Utermöhl settling chambers (Utermöhl, 1958) and an inverted phase contrast microscope (Zeiss Axio Observer, Germany). A minimum of 400 cells per sample were counted, using $400 \times$ magnification until 200 cells were counted and $100 \times$ magnification for the remaining 200 cells. This ensured that both larger and smaller cells were accounted for. A minimum of 10 fields were counted with each magnification. Biovolume estimates were based on geometrical models and cell measurements using photography and the AxioVision software (Zeiss, Germany) and converted using carbon to volume relationships (Menden-Deuer and Lessard, 2000). Phytoplankton taxonomy relied on the following literature: Cox (1996), Hillebrand et al. (1999); John et al. (2002), Komárek and Anagnostidis (2000), Guiry and Guiry (2017), Taylor et al. (2007), and Wehr et al. (2015). Taxa were identified to the genus level when possible but later grouped by class for comparisons. One phytoplankton sample $(150 \mathrm{~mL})$ was taken for each sampling, day $1,3,5,10$. Three samples had insufficient preservation and could not be quantified.

\subsection{Data analysis}

A general linear model was used to test for differences in the rate of nutrient loss from our organic matter treatments (goose droppings or Carex clippings). Time (d), time ${ }^{2}$, treatment and their interactions were included as predictors, and nutrients $(\mathrm{C}, \mathrm{N}, \mathrm{P}, \mathrm{N}: \mathrm{P}$ ratio) measured in the organic matter were the response variables. A similar analysis was conducted for the corresponding changes to nutrient concentrations in the experimental water. To visualize results, we fit a quadratic function with a $95 \%$ confidence interval (CI) to the relationship between TP and TN concentrations in the water and time, throughout the experiment, using ggplot2 (Wickham, 2009). Visual inspection of residual plots did not reveal any obvious deviations from homoscedasticity or normality (Zuur et al., 2010). $P$ values were obtained by likelihood ratio tests. Phytoplankton biodiversity was calculated using the Shannon-Wiener (alpha diversity) index. All analyses were conducted using $\mathrm{R}$ software $(\mathrm{R}$ version 3.1.1; $\mathrm{R}$ Core Team, 2016), and all means are reported \pm SD unless otherwise noted.

\section{Results}

\subsection{Nutrients released from submerged organic matter}

The initial composition of the solid material showed that goose droppings had higher water content compared to Carex, a significantly higher percentage of nitrogen and phosphorous, and a significantly lower content of carbon and $\mathrm{N}$ : $\mathrm{P}$ ratio (Tables 1, 2a, b, c). Once submerged, the carbon remained largely intact, showing a small but statistically significant loss of around $2 \%$ for goose droppings and $5 \%$ for Carex (Fig. 2a, Table 2a). Losses of nitrogen and phosphorus were much more rapid for the goose dropping treatment. After only $1 \mathrm{~d}$, the goose droppings had released $48 \%$ of the original nitrogen and $43 \%$ of the original phosphorous, with no additional significant release of nutrients throughout the rest of the $17 \mathrm{~d}$ experiment (Fig. 2b, c). In contrast, there was no net loss of nitrogen or phosphorus from Carex over the experimental period (Fig. $2 \mathrm{~b}, \mathrm{c}$ ). The $\mathrm{N}: \mathrm{P}$ ratio stayed between 8 and 10 for the goose dropping treatment, while the $\mathrm{N}$ : P ratio for Carex fluctuated between 11 and 14 (Fig. 2d). Despite the rapid loss of nutrients from the goose droppings, phosphorous remained higher in the goose droppings compared to Carex at the end of the experiment (Fig. 2).

\subsection{Nutrients released into the water}

The nutrients released from the organic matter caused reciprocal changes in water chemistry during the experiment. The dissolved TN and TP in the water of the goose dropping 
(a)

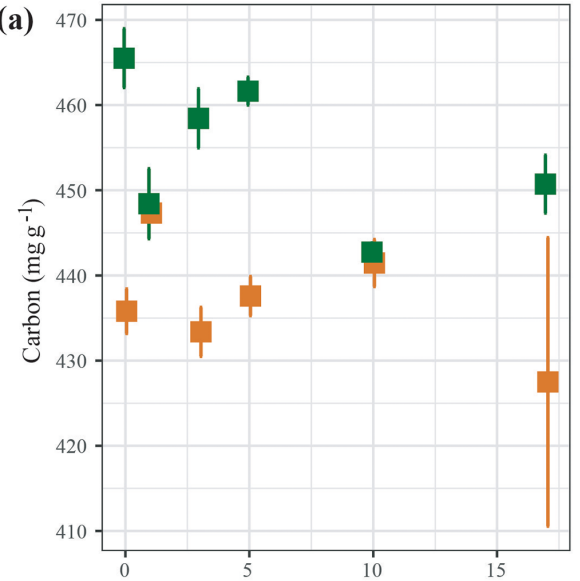

(c)

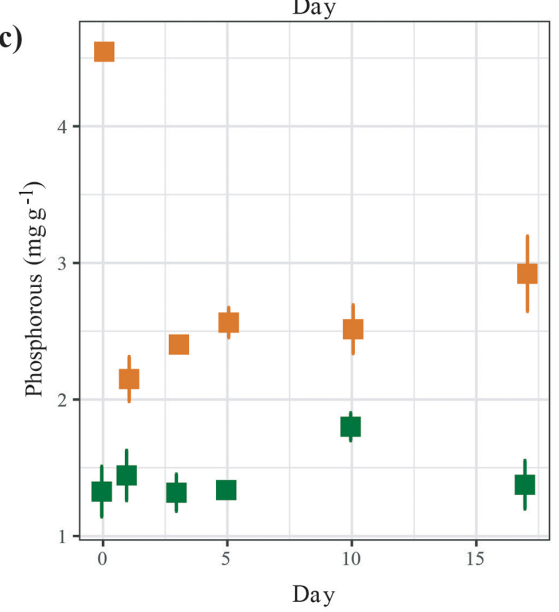

(b)

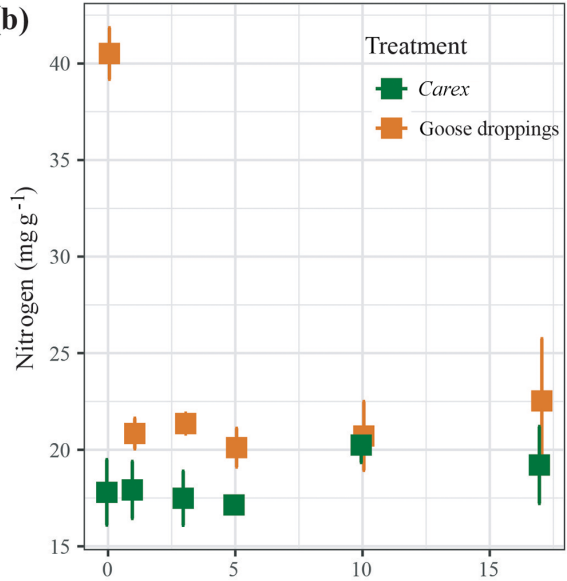

(d)

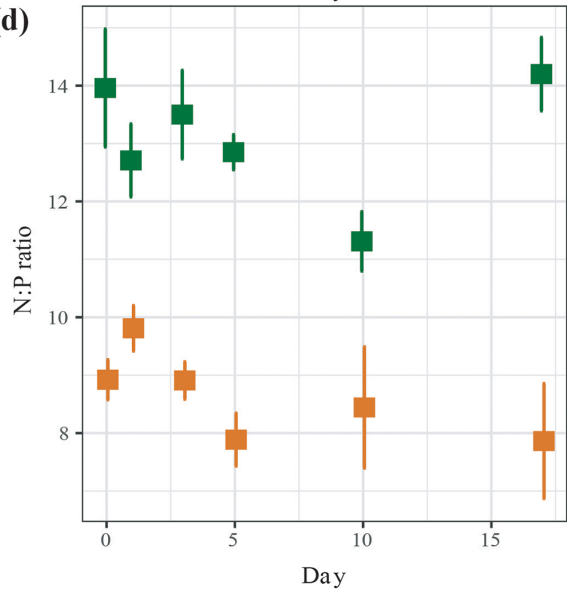

Figure 2. The decomposition of (a) carbon, (b) nitrogen, (c) phosphorus, and (d) nitrogen : phosphorous ratio from submerged organic material of Carex clippings and goose droppings, reported as mean $\pm \mathrm{SE}$ across replicated $(n=5)$ throughout the $17 \mathrm{~d}$ experiment.
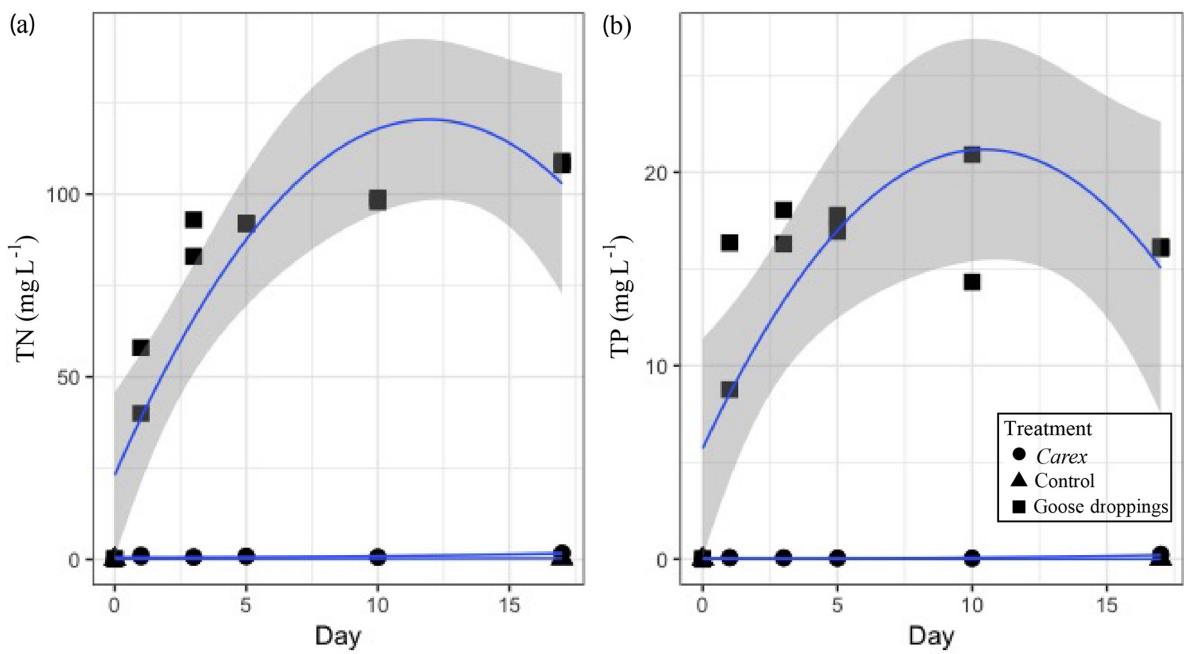

Figure 3. The cumulative nutrient concentrations released from goose droppings and Carex sp. into the water column: (a) total dissolved nitrogen (TN) and (b) total dissolved phosphorus (TP) in $\mathrm{mg} \mathrm{L}^{-1}$ over the $17 \mathrm{~d}$ mesocosm experiment. Dots represent individual samples on each day duplicate samples were taken. Quadratic function used to fit data with the shaded area representing the $95 \%$ confidence interval. 
Table 2. Summary of results from general linear models comparing (a) carbon, (b) nitrogen, and (c) phosphorus between the solid organic matter of Carex and goose dropping treatments and (d) total dissolved nitrogen and (e) total dissolved phosphorous in the overlaying water. Significant values are in bold.

\begin{tabular}{|c|c|c|c|c|c|}
\hline & Source & Degrees of freedom & MS & $\mathrm{F}$ & $p$ value \\
\hline \multirow{6}{*}{ (a) Carbon } & treatment & 1 & 4543.1 & 26.4 & $<0.001$ \\
\hline & time & 1 & 837.4 & 4.9 & $\mathbf{0 . 0 3}$ \\
\hline & time $^{2}$ & 1 & 0 & 0.01 & 0.99 \\
\hline & treatment : time & 1 & 6 & 0.03 & 0.85 \\
\hline & treatment : time ${ }^{2}$ & 1 & 240.3 & 1.3 & 0.244 \\
\hline & Residuals & 54 & 173.8 & & \\
\hline \multirow{7}{*}{ (b) Nitrogen } & intercept & 1 & & & \\
\hline & treatment & 1 & 548 & 20.58 & $<0.001$ \\
\hline & time & 1 & 66.6 & 2.5 & 0.11 \\
\hline & time $^{2}$ & 1 & 234.14 & 8.7 & 0.004 \\
\hline & treatment : time & 1 & 194 & 7.2 & 0.008 \\
\hline & treatment: time $^{2}$ & 1 & 270 & 10.1 & 0.002 \\
\hline & Residuals & 54 & 26.62 & & \\
\hline \multirow{6}{*}{ (c) Phosphorus } & treatment & 1 & 30.1 & 85.9 & $<0.001$ \\
\hline & time & 1 & 0.17 & 0.38 & 0.49 \\
\hline & time $^{2}$ & 1 & 1.6 & 4.7 & 0.03 \\
\hline & treatment : time & 1 & 0.67 & 1.9 & 0.17 \\
\hline & treatment : time ${ }^{2}$ & 1 & 3.9 & 11.2 & 0.001 \\
\hline & Residuals & 54 & 0.35 & & \\
\hline \multirow{7}{*}{ (d) TN dissolved } & intercept & & & & 0.953 \\
\hline & treatment & 2 & 35553 & 107.3 & $<0.001$ \\
\hline & time & 1 & 3572 & 21.6 & $<0.001$ \\
\hline & time $^{2}$ & 1 & 2162 & 13.1 & 0.001 \\
\hline & treatment : time & 2 & 5749 & 17.4 & $<0.001$ \\
\hline & treatment: time $^{2}$ & 1 & 2185 & 13.2 & 0.002 \\
\hline & Residuals & 20 & 3312 & & \\
\hline \multirow{6}{*}{ (e) TP dissolved } & treatment & 2 & 616.6 & 59.6 & $<0.001$ \\
\hline & time & 1 & 49.7 & 4.8 & 0.04 \\
\hline & time $^{2}$ & 1 & 92.5 & 8.9 & 0.007 \\
\hline & treatment : time & 2 & 39.5 & 3.8 & 0.04 \\
\hline & treatment : time ${ }^{2}$ & 1 & 94.6 & 9.1 & 0.007 \\
\hline & Residuals & 20 & 10.4 & & \\
\hline
\end{tabular}

treatment were orders of magnitude higher than the concentrations found in the water of the Carex treatment (Fig. 3). By the end of the experiment (day 17), the water in the goose treatment contained $108 \mathrm{mg} \mathrm{L}^{-1} \mathrm{TN}$, while the water in the Carex treatment had $1.6 \mathrm{mgL}^{-1} \mathrm{TN}$, compared with $0.1 \mathrm{mg} \mathrm{L}^{-1}$ in the pond water initially, or the $0.6 \mathrm{mg} \mathrm{L}^{-1}$ average TN from Southampton lakes (Mariash et al., 2018). Similarly, for TP, higher concentrations were found in the water of the goose treatment compared to the Carex treatment (16 mg L ${ }^{-1} \mathrm{TP}$ compared to $0.2 \mathrm{mgL}^{-1} \mathrm{TP}$, respectively). The initial pond water concentration was $0.002 \mathrm{mg} \mathrm{L}^{-1} \mathrm{TP}$, compared to an average TP concentration for local ponds of $0.01 \mathrm{mg} \mathrm{L}^{-1}$. For total dissolved nitrogen, there was a significant main effect of treatment (Carex vs. droppings; Table 2d). There was also a significant interaction between treatment and time (and time ${ }^{2}$; Table 2d, Fig. 3a), indicating a larger increase over time for the goose dropping treatment. Total dissolved phosphorus showed similar patterns, with a significant treatment effect, and significant time ${ }^{2}$ and time ${ }^{2} \cdot$ treat- $^{-}$ ment effects (Table 2e, Fig. 3b).

\subsection{Phytoplankton biovolumes and composition}

Each treatment contained diverse phytoplankton communities and showed increased biovolumes over the course of the experiment. The initial phytoplankton biovolume was low at only $0.1 \mathrm{~mm}^{3} \mathrm{~L}^{-1}$. For both treatments, phytoplankton biovolumes increased during the experiment, reaching $4.6 \pm 0.2 \mathrm{~mm}^{3} \mathrm{~L}^{-1}$ by day 10 (Fig. 4). While the biovolumes were similar, the phytoplankton communities were different 

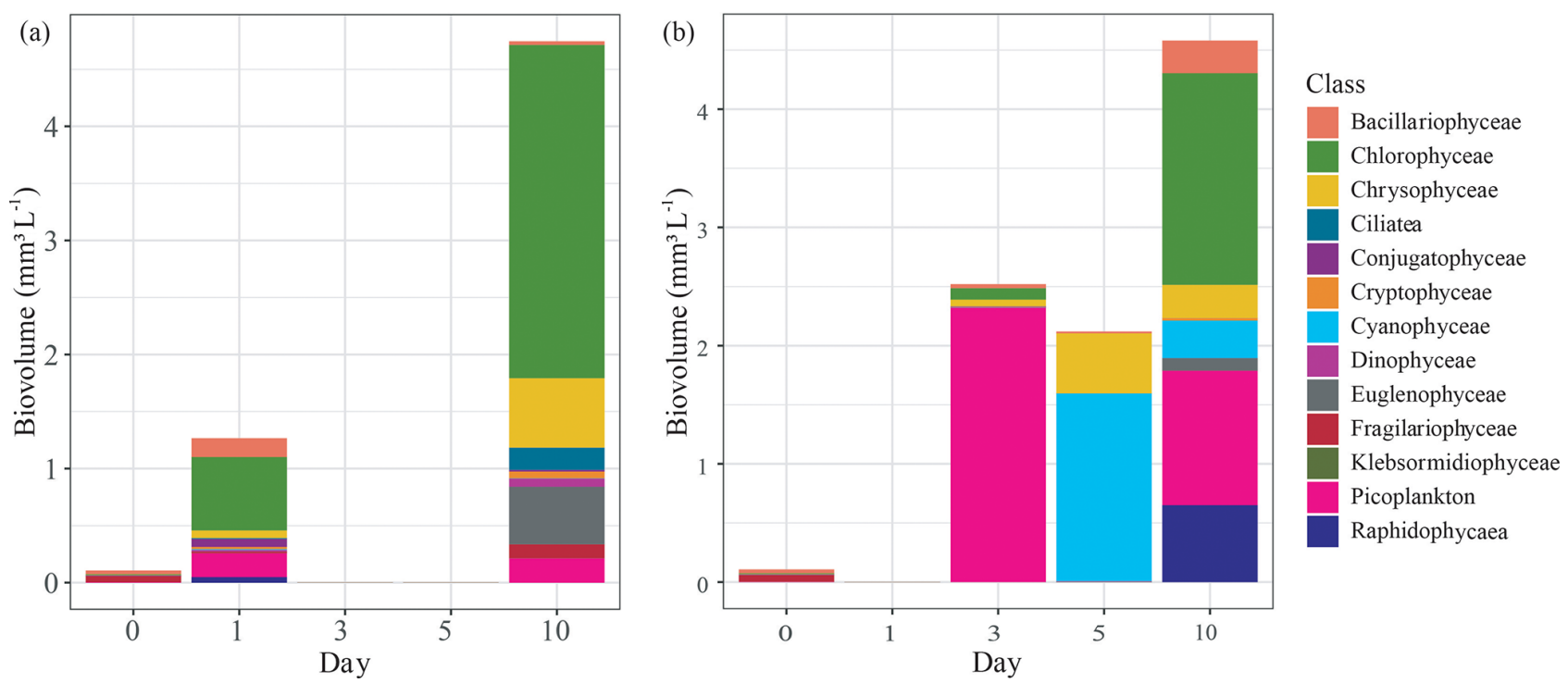

Figure 4. Change in phytoplankton community composition by biovolume $\left(\mathrm{mm}^{3} \mathrm{~L}^{-1}\right)$ grouped by class, measured over the first $10 \mathrm{~d}$ of the mesocosm experiment that used either submerged (a) Carex sp. or (b) goose droppings to stimulate phytoplankton production in lake water. Missing values were due to incomplete preservation of those samples.

between treatments. In the Carex treatment, phytoplankton growth on day 1 had risen to $1.2 \mathrm{~mm}^{3} \mathrm{~L}^{-1}$, which was mainly from the production of chlorophytes $\left(0.64 \mathrm{~mm}^{3} \mathrm{~L}^{-1} ; 50 \%\right.$ of total biovolume), picoplankton $\left(0.21 \mathrm{~mm}^{3} \mathrm{~L}^{-1} ; 16 \%\right)$, and bacillariophytes $\left(0.16 \mathrm{~mm}^{3} \mathrm{~L}^{-1} ; 13 \%\right.$, diatoms) (Fig. 4a). In the goose dropping treatment, phytoplankton biovolumes had doubled in the Carex treatment, to a total of $2.5 \mathrm{~mm}^{3} \mathrm{~L}^{-1}$ on day 3 (Fig. 4b). There was no rise in phytoplankton biovolume between days 3 and 5, but biovolume doubled again between days 5 and 10 to $4.6 \mathrm{~mm}^{3} \mathrm{~L}^{-1}$. Dominant phytoplankton in the goose dropping treatment were mainly picoplankton, accounting for $2.3 \mathrm{~mm}^{3} \mathrm{~L}^{-1}(92 \%)$, chlorophytes, accounting $0.1 \mathrm{~mm}^{3} \mathrm{~L}^{-1}$, and $0.06 \mathrm{~mm}^{3} \mathrm{~L}^{-1}$ Chrysophyceae on day 3 but rapidly changed to cyanobacteria $(75 \%)$ on day 5 (Fig. 4b). Cyanobacteria was no longer the main class but remained high on day 10 .

The goose treatment had fewer taxa than the Carex treatment, with only 10 taxa present, represented by 8 classes. The most abundant taxa were Chlorella, Ochromonas, Aphanocapsa, and Gonyostomum, the latter being attributed to nuisance algal blooms. For the Carex treatment, the phytoplankton community was diverse at day 10, with 19 taxa, represented by 12 classes but was clearly dominated by Chlamydomonas a green algae (Chlorophyceae; $50 \%$ ) on day 10 (Fig. 4a). Cyanobacteria were not observed in the phytoplankton community of the Carex treatment.

These differences in phytoplankton communities among treatments were also confirmed with diversity indices. Initially, the pond water had a Shannon-Wiener index of 1.9 with 16 taxa present. This increased to 2.2 and 2.3 on days 1 and 10, respectively, for the Carex treatment. For the goose droppings treatment, the Shannon-Wiener index declined to 1.8 on days 3 and 5 , then returned to 1.9 on day 10 .

\section{Discussion}

Previous studies have suggested that geese can act as an important vector of nutrients (especially $\mathrm{N}$ and $\mathrm{P}$ ) from terrestrial to aquatic systems, and this nutrient transfer might be especially important in otherwise oligotrophic Arctic ponds (Dessborn et al., 2016). However, studies from the Arctic are rare (Mariash et al., 2018; Mallory et al., 2006), and none to date have assessed the ecosystem response of goose-related eutrophication by linking the nutrient levels to phytoplankton growth and community responses. Our experimental field trials in wetlands on Southampton Island, Nunavut, provided evidence that submerged goose droppings leach a significant amount of nitrogen and phosphorous, immediately elevating the nutrient concentrations in the water. The leached nutrients were bioavailable, rapidly increasing phytoplankton biovolume and altering community composition. Both treatments showed diverse phytoplankton communities; however, only in the goose dropping treatment did cyanobacteria become dominant. Collectively, these results demonstrate the direct ecological consequences of ornithogenic nutrient loading in Arctic freshwater ecosystems.

\subsection{Nutrients released from submerged organic matter into the water}

Once submerged, goose droppings released approximately $45 \%$ of the nitrogen and phosphorus that they contained on the first day. In a previous study, Liu et al. (2014) demon- 
strated that most nutrients were released from goose droppings in the first $10 \mathrm{~d}$, but they did not measure the nutrient concentrations in the water. Also, our mesocosm approach allowed for natural light, temperature, and some mixing, along with more comprehensive tracking of the nutrients released from the goose droppings into the water and the resultant effects on primary producers. We showed that this rapid release of $\mathrm{N}$ and $\mathrm{P}$ from goose droppings resulted in a rapid increase in TN and TP concentrations in the water column. The nutrient concentrations in the water continued to increase until a peak at day 10, then concentrations of TN and TP showed signs of decreasing on day 17 , when nutrients were presumably assimilated by phytoplankton.

Our mesocosm approach demonstrated that under natural light and temperature conditions, the release of nutrients from Carex and goose droppings, and the final dissolved nutrient concentrations in the water column, were quite different. While the Carex clippings themselves were relatively Nrich, measuring $18 \mathrm{mg} \mathrm{N} \mathrm{g}^{-1}$ (nearly half of the concentration of $\mathrm{N}$ in goose droppings), there was no net change in nitrogen in the water column from Carex during our experiment. This was similar to the nutrient release dynamics found in Liu et al. (2014), where the Carex at $10^{\circ} \mathrm{C}$ had an immobilization phase within the first $5 \mathrm{~d}$. In contrast, submerged goose droppings had a peak of nutrient release in the first day, while much of the remaining nutrients in the goose droppings were retained over the next $17 \mathrm{~d}$. This high retention of the remaining P, approximately $50 \%$ over $17 \mathrm{~d}$, has also been observed in other experiments (Liu et al., 2014). These retained nutrients in residual organic matter can settle into the sediment (Unckless and Makarewicz, 2007), where they can build up and later be resuspended by a strong wind event. Additionally, the differences in the fractions of labile and recalcitrant nutrients may play a crucial role in the degree to which the nutrients contained in droppings versus Carex are available to influence productivity. Both a quick release of half the nutrients and sedimentation of the other half of the nutrients in Arctic wetlands, in combination with high evaporation and low flushing rates, may further concentrate the nutrients leading to late summer eutrophic conditions (Lewis et al., 2015; Mariash et al., 2018).

While the experiment was helpful to demonstrate the rate of nutrients leaching into the water, the concentrations of goose droppings used were higher than natural loading rates calculated for Southampton Island goose colonies. To demonstrate loading rates on a landscape scale, we compared natural loading rates and water chemistry changes from studies in goose colonies (Table 3). These studies reported a wide range of nutrient concentrations arising from natural droppings into the environment and experimental additions. The highest reported natural loading rates were found in the southern wintering grounds, with 9$15 \mathrm{~kg} \mathrm{k} \mathrm{km}^{-2} \mathrm{~d}^{-1}$ and $0.9-1.5 \mathrm{~kg} \mathrm{~km}^{-2} \mathrm{~d}^{-1}$. In comparison, Schindler et al. (2008) added, on average, $298 \mathrm{~kg}$ of N and $24 \mathrm{~kg}$ of $\mathrm{P}$ per year to a small boreal lake annually for the first 6 years of their classic whole-lake eutrophication experiment. Since the amounts of $\mathrm{N}$ and $\mathrm{P}$ additions varied from year to year, an average of nutrient additions for the first 6 years was used, and then divided by 365 to get a daily loading rate. The daily load per lake area of $\mathrm{N}$ and $\mathrm{P}$ additions from their whole-lake experiment was smaller than nutrient loads produced by goose colonies (Table 3). Nutrient loads from geese translated into increases in both TN and TP in the water along with high Chl $a$ (Table 3 ) for all studies compared. Clearly, after entering the water body, many factors affect nutrient dynamics in the water, including residence time, depth, stratification, and algae biovolume (Anderson et al., 2017). Nonetheless, despite the differences in climate and hydrology in these studies, dissolved TN and TP were highest where the nutrient loads were highest. Moreover, at the landscape level, these nutrient load changes related to geese were occurring at a much faster pace than water chemistry changes caused by climate variables (Mariash et al., 2018).

\subsection{Phytoplankton response}

Chlorophyll $a$ (Chl $a$ ) concentrations in shallow freshwaters averaged $1.9 \mu \mathrm{gL}^{-1}$ across the circumpolar Arctic (Rautio et al., 2011), concentrations in pristine ponds in southwestern Greenland were lower, at $0.5 \mu \mathrm{g} \mathrm{L}^{-1}$ (Mariash et al., 2014), while ponds on Southampton Island were slightly above that circumpolar average with $2.2 \mu \mathrm{gL}^{-1} \mathrm{Chl} a$. In more southerly temperate wetlands, with higher nutrient loads from geese, $\mathrm{Chl} a$ is orders of magnitude higher, with concentrations between 27 and $800 \mu \mathrm{gL}^{-1}$ (Kitchell et al., 1999). We had expected phytoplankton biovolumes to be higher in the goose dropping treatment vs. the Carex treatment; however, the phytoplankton biovolume was similar between the two treatments by the end of day 10, showing that the input of nutrients derived from either treatment was enough for a phytoplankton response in these oligotrophic waters. Temperature may be another important factor limiting productivity; given enough nutrients, both light and temperature can restrict phytoplankton growth (Fanesi et al., 2016). Also, high concentrations of submerged Carex would occur primarily only along pond margins during periods of inundation, such as during the spring freshet, or when shoots are pulled by grazing geese to consume the starchy base of the leaves. Thus, nutrients released from Carex may be insignificant compared to goose droppings at a landscape scale.

Community composition of the phytoplankton responded to increased nutrient availability in both treatments. Our experimental design was not without issues: more replicates would have made the results clearer, and the use of small containers has the potential to contribute technique-related artefacts (e.g., biofilm growth, altered physiochemical conditions and species interactions due to container area-to-volume relationship; Liber et al., 2007). Due to these limiting factors, the experiment can best be used to show the biological impli- 
Table 3. Comparison of the loading rates of nitrogen $(\mathrm{N})$ and phosphorus $(\mathrm{P})$ from geese and these nutrients in dissolved form $(\mathrm{TN}$, TP) in the water, along with the chlorophyll $a(\mathrm{Chl} a)$ concentrations found in the waterbodies. Loading rates are in kilograms of nutrients per the density of geese per square kilometre at a given site per day.

\begin{tabular}{|c|c|c|c|c|c|c|c|c|}
\hline \multirow[b]{2}{*}{ Location } & \multirow[b]{2}{*}{ Study } & \multicolumn{3}{|c|}{ Nutrient load } & \multicolumn{4}{|c|}{ Water } \\
\hline & & $\mathrm{kg} \mathrm{km}^{-2} \mathrm{~d}^{-1}$ & $\mathrm{~kg} \mathrm{~km}^{-2} \mathrm{~d}^{-1}$ & $\mathrm{~N}: \mathrm{P}$ & $\begin{array}{r}\mathrm{TN} \\
\mathrm{mgL}^{-1}\end{array}$ & $\begin{array}{r}\mathrm{TP} \\
\mathrm{mgL}^{-1}\end{array}$ & $\mathrm{TN}: \mathrm{TP}$ & $\begin{array}{r}\text { Chl } a \\
\mu g L^{-1}\end{array}$ \\
\hline Rio Grande River, USA & Kitchell et al. (1999) & 15.68 & 1.52 & 10.3 & 35.00 & 2.50 & 15.0 & 800.0 \\
\hline Middle Creek Reservoir, USA & Olson et al. (2005) & 8.90 & 0.86 & 10.3 & 4.00 & 0.08 & 53.3 & 94.3 \\
\hline Southampton Island, Canada & Mariash et al. (2018) & 4.46 & 0.50 & 8.9 & 0.45 & 0.02 & 30.1 & 2.2 \\
\hline Ontario, Canada & Schindler et al. (2008) & 2.72 & 0.22 & 12.4 & 0.83 & 0.04 & 20.8 & 27.0 \\
\hline
\end{tabular}

High bird density loads are reported from Kitchell et al. (1999). For Olson et al. (2005), the average nutrient loads for inflow and outflow are reported. For Southampton Island (SHI), values are the average of the 26 shallow waterbodies surveyed in 2015 (see Mariash et al., 2018, for survey details). Schindler et al. (2008) values are the average nutrient addition from the first 6 years when TN and TP were added with a similar ratio to the ratio found in goose droppings (after year 6 , only P was added).

cations of the released nutrients and potential phytoplankton response. Initially dominated by diatoms, the phytoplankton community of the Carex treatment changed to having a more diverse community, with the dominant class being green algae. The phytoplankton community in the goose dropping treatment initially had only 10 taxa present represented by 8 classes, but by day 5 the community was dominated $(98 \%)$ by cyanobacteria (Aphanocapsa and Pseudanabaena) and chrysophytes (Ochromonas). A similar pattern in dominance of cyanobacteria and cryophytes is consistent with results in other nutrient-enrichment studies (Paerl et al., 2016; Przytulska et al., 2017). Cyanobacteria can out-compete other taxa when both nitrogen and phosphorous concentrations are high (Paerl et al., 2016; Schindler et al., 2008). High abundance of cyanobacteria will negatively affect species richness and diversity, as seen in the diminishing presence of other phytoplankton classes in our experiment.

$\mathrm{N}$-limitation of algae growth can occur at TN : TP ratios $<20$ (Findlay et al., 1994; Guildford and Hecky, 2000). In Schindler et al. (2008), the presence of cyanobacteria peaked within weeks after reducing the TN : TP from 12 to 4 . Goose droppings in this study had an $\mathrm{N}: \mathrm{P}$ ratio of 10 , and when placed in water in our experimental treatment, they lowered the TN: TP ratio to 5.4, demonstrating goose droppings have the potential to significantly alter the ambient nutrient balance. Relatively phosphorous-rich goose droppings can cause nitrogen limitation in freshwaters (Mariash et al., 2018; Post et al., 1998; Schindler et al., 2008). This is an environmental concern from a water quality perspective because when $\mathrm{N}$ is limiting, $\mathrm{N}_{2}$-fixing cyanobacteria are competitively favoured (Guildford and Hecky, 2000; Schindler et al., 2008). The wetlands across Southampton Island have relatively low nitrogen concentration and $\mathrm{TN}$ : $\mathrm{TP}$ ratios of approximately 30 (Mariash et al., 2018), on par with other shallow Arctic freshwaters (Rautio et al., 2011), there is an indication that these wetlands are becoming more N-limited with decreasing TN : TP ratios (Mariash et al., 2018).

Geese are very inefficient herbivores, excreting approximately $60 \%$ of their ingested nutrients (Kitchell et al., 1999), and these nutrients are quickly released into the aquatic environment as demonstrated by the rapid release of nutrients from the organic matter in our goose dropping treatment. Once released, these nutrients are bioavailable, altering water chemistry and likely phytoplankton communities of the watershed. On Southampton Island, graminoids such as Carex spp. are the primary diet source for the geese, and our experiment demonstrates that only when passed through geese was the nitrogen and phosphorus bound in the Carex released into the water. Geese are therefore acting as bio-vectors on the landscape, consuming large amounts of terrestrial nutrients bound in vegetation and excreting these nutrients in a form that is bioavailable for freshwater ecosystems. Goose faeces could also contribute to the dispersal of aquatic species, altering aquatic communities in this direct manner (Figuerola and Green, 2002). Tested phytoplankton species were not viable under cultured conditions once passed through water birds (Atkinson, 1980); however, tests of this mechanism have not yet been carried out for geese in the Arctic.

As geese are long-distance migrants, and as many circumpolar Arctic goose populations have increased substantially (Fox and Leafloor, 2018), their movement and effects on the aquatic habitats have implications across Arctic North America and Europe at locations where geese congregate in large numbers. Management strategies for hyper-abundant geese currently emphasize the need for maintaining the ecological integrity of terrestrial habitats. Our results demonstrate that the impacts of geese extend to freshwater Arctic ecosystems, and future management strategies should better acknowledge these aquatic impacts.

Data availability. The data will be made freely available on the Government of Canada's OpenData portal.

Author contributions. All authors contributed to conceptualization and experimental design. HLM and PAS executed the experiments in the field. MR analyzed the phytoplankton samples. HLM ana- 
lyzed all data and prepared the manuscript, with contributions from all authors.

Competing interests. The authors declare that they have no conflict of interest.

Acknowledgements. We are grateful for the efforts of the East Bay field crew and to Christian Schwarz for discussions that greatly improved this work.

Financial support. Financial support for data collection and analyses were provided in part by the Arctic Goose Joint Venture, the Canadian Wildlife Service, the Wildlife Research Division of Environment and Climate Change Canada, Canada Research Chair Program, and the Polar Continental Shelf Program. Heather L. Mariash was supported by a W. Garfield Weston Fellowship for Northern Studies.

Review statement. This paper was edited by Perran Cook and reviewed by two anonymous referees.

\section{References}

Abraham, K. F., Jefferies, R. L., and Alisauskas, R. T.: The dynamics of landscape change and snow geese in midcontinent North America, Glob. Change Biol., 11, 841-855, https://doi.org/10.1111/j.1365-2486.2005.00943.x, 2005.

Abraham, K. F., Jefferies, R. L., Alisauskas, R. T., and Rockwell, R. F.: Evaluation of special management measures for midcontinent lesser snow geese and Ross's geese, in: Northern wetland ecosystems and their response to high densities of lesser snow geese and Ross's geese, edited by: Leafloor, J. O., Moser, T. J., and Batt, B. D., pp. 9-45, Arctic Goose Joint Venture publication, US Fish and WIldlife Service and Canadian Wildlife Service, Washington, D.C. and Ottawa, Ontario, 2012.

Anderson, J. N., Saros, J. E., Bullard, J. E., Cahoon, S. M., McGowan, S., Bagshaw, E. A., Barry, C. D., Bindler, R., Burpee, B. T., Carrivick, J., Fowler, R. A., Fox, A. D., Fritz, S. C., Hamerlik, L., Ingeman-Nielsen, T., Law, A. C., Mernild, S. H., Northington, R. M., Osburn, C. L., Pla-Rabes, S., Post, E., Telling, J., Stroud, D. A., Whiteford, E. J., Yallop, M. L., and Yde, J. C.: The Arctic in the Twenty-First Century?: Changing Biogeochemical Linkages across a Paraglacial Landscape of Greenland, Bioscience, 67, 118-133, https://doi.org/10.1093/biosci/biw158, 2017.

Ask, J., Karlsson, J., Persson, L., and Ask, P.: Terrestrial organic matter and light penetration: Effects on bacterial and primary production in lakes, Limnol. Oceanogr., 54, 2034-2040, 2009.

Atkinson, K.: Experiments in dispersal of phytoplankton by ducks, British Phycological Journal, 15, 49-58, https://doi.org/10.1080/00071618000650061, 1980.

Buij, R., Melman, T. C. P., Loonen, M. J. J. E., and Fox, A. D.: Balancing ecosystem function, services and disservices result- ing from expanding goose populations, Ambio, 46, 301-318, https://doi.org/10.1007/s13280-017-0902-1, 2017.

Cadieux, A. M., Gauthier, G., Hughes, R. J., Auk, S. T., and Jan, N.: Feeding Ecology of Canada Geese (Branta canadensis interior) in Sub-Arctic Inland Tundra during Brood-Rearing, Am. Ornithol. Union, 122, 144-157, 2005.

Côté, G., Pienitz, R., Velle, G., and Wang, X.: Impact of Geese on the Limnology of Lakes and Ponds from Bylot Island (Nunavut, Canada), Int. Rev. Hydrobiol., 95, 105-129, https://doi.org/10.1002/iroh.200911151, 2010.

Cox, E. J.: Identification of freshwater diatoms from live material, Chapman \& Hall, London, UK, 1996.

Dessborn, L., Hessel, R., and Elmberg, J.: Geese as vectors of nitrogen and phosphorous to freshwater systems, Inl. Waters, 6, 111-122, https://doi.org/10.5268/IW-6.1.897, 2016.

Fanesi, A., Wagner, H., Becker, A., and Wilhelm, C.: Temperature affects the partitioning of absorbed light energy in freshwater phytoplankton, Freshw. Biol., 61, 1365-1378, https://doi.org/10.1111/fwb.12777, 2016.

Figuerola, J. and Green, A. J.: Dispersal of aquatic organisms by waterbirds: $A$ review of past research and priorities for future studies, Freshw. Biol., 47, 483-494, https://doi.org/10.1046/j.1365-2427.2002.00829.x, 2002.

Findlay, D. L., Hecky, R. E., Hendzel, L. L., Stainton, M. P., and Regehr, G. W.: Relationship between $\mathrm{N}_{2}$-fixation and heterocyst abundance and its relevance to the nitrogen budget of lake 227, Can. J. Fish. Aquat. Sci., 51, 2254-2266, https://doi.org/10.1139/f94-229, 1994.

Flemming, S. A., Nol, E., Kennedy, L. V., and Smith, P. A.: Hyperabundant herbivores limit habitat availability and influence nest site selection of Arctic-breeding birds, J. Appl. Ecol., 5, 1-12, https://doi.org/10.1111/1365-2664.13336, 2019.

Fox, A. D. and Leafloor, J. O.: A Global Audit of the Status and Trends of Arctic And Northern Hemisphere Goose Populations, Akureyri, Iceland, 2018.

Gauthier, G., Hughes, R. . J., Reed, A., Beaulieu, J., and Rochefort, L.: Effect of Grazing by Greater Snow Geese on the Production of Graminoids at an Arctic Site, Br. Ecol. Soc., 83, 653-664, 1995.

Guildford, S. J. and Hecky, R. E.: Total nitrogen, total phosphorus, and nutrient limitation in lakes and oceans: Is there a common relationship?, Limnol. Oceanogr., 45, 1213-1223, https://doi.org/10.4319/lo.2000.45.6.1213, 2000.

Guiry, M. D. and Guiry, G. M.: AlgaeBase. World-wide electronic publication, National University of Ireland, Galway, available at: https://www.algaebase.org/, last access: 28 November 2017.

Hessen, D. O., Jensen, T. C., and Walseng, B.: Zooplankton Diversity and Dispersal by Birds; Insights From Different Geographical Scales, Front. Ecol. Evol., 7, 74, https://doi.org/10.3389/fevo.2019.00074, 2019.

Hillebrand, H., Dürselen, D., Kirschtel, D., Pollingher, U., and Zohary, T.: Biovolume Calculation For Pelagic And Benthic MicroAlgae, J. Phycol., 35, 403-424, 1999,

Holm-Hansen, O. and Riemann, B.: Chlorophyll a determination?: improvements in methodology, Oikos, 30, 438-447, https://doi.org/10.2307/3543338, 1978.

Jefferies, R. L., Jano, A. P., and Abraham, K. F.: A biotic agent promotes large-scale catastrophic change in the 
coastal marshes of Hudson Bay, J. Ecol., 94, 234-242, https://doi.org/10.1111/j.1365-2745.2005.01086.x, 2006.

Jeffrey, S. W., Mantoura, R. F. C., and Wright, S. W.: Spectrophotometric and fluorometric equations in common use in oceangraphy, in: Phytoplankton Pigments in Oceanography: Guidelines to Modern Methods, 48, 597-615, UNESC Publishing, Paris, 1997.

John, D. M., Whitton, B. A., and Brook, A. J.: The freshwater algal flora of the British Isles: an identification guide to freshwater and terrestrial Algae (Vol. 1), Cambridge University Press, Cambridge, UK, 2002.

Kerbes, R. H., Meeres, K. M., and Alisauskas, R. T.: Surveys of nesting lesser snow geese and ross's geese in arctic Canada, 2002-2009, Arct. Goose Jt. Ventur. Spec. Publ. U.S. Fish Wildl. Serv. Washingt. D.D. Can. Wildl. Serv. Ottawa, Ontario, 20022009, 2014.

Kitchell, J. F., Schindler, D. E., Herwig, B. R., Post, D. M., Olson, M. H., and Oldham, M.: Nutrient cycling at the landscape scale: The role of diel foraging migrations by geese at the Bosque del Apache National Wildlife Refuge, New Mexico, Limnol. Oceanogr., 44, 828-836, https://doi.org/10.4319/lo.1999.44.3_part_2.0828, 1999.

Komárek, J. and Anagnostidis, K.: Cyanoprokaryota Teil-1, 2, 3: Chroococcales, Spektrum Akademischer Verlag Heidelberg, Berlin, ISBN 978-3-7482-2111-1, 2000.

Lewis, T. L., Lindberg, M. S., Schmutz, J. A., and Heglund, P. J.: Pronounced chemical response of Subarctic lakes to climatedriven losses in surface area, Glob. Change Biol., 21, 1140-1152, https://doi.org/10.1111/gcb.12759, 2015.

Liber, K., Goodfellow, W., den Besten, P., Clements, W., Galloway, T., Gerhardt, A., Green, A., and Simpson, S.: In situbased effects measures: considerations for improving methods and approaches, Integr. Environ. Assess. Manag., 3, 246-258, https://doi.org/10.1897/2006-029FIN.1, 2007.

Liu, Y., Hefting, M. M., Verhoeven, J. T. A., and Klaassen, M.: Nutrient release characteristics from droppings of grass-foraging waterfowl (Anser brachyrhynchus) roosting in aquatic habitats, Ecohydrology, 7, 1216-1222, https://doi.org/10.1002/eco.1454, 2014

MacDonald, L. A., Farquharson, N., Merritt, G., Fooks, S., Medeiros, A. S., Hall, R. I., Wolfe, B. B., Macrae, M. L., and Sweetman, J. N.: Limnological regime shifts caused by climate warming and Lesser Snow Goose population expansion in the western Hudson Bay Lowlands (Manitoba, Canada), Ecol. Evol., 5, 921-939, https://doi.org/10.1002/ece3.1354, 2015.

Mallory, M. L., Fontaine, A. J., Smith, P. A., Wiebe Robertson, M. O., and Gilchrist, H. G.: Water chemistry of ponds on Southampton Island, Nunavut, Canada: effects of habitat and ornithogenic inputs, Archiv für Hydrobiologie, 166, 411-432, 2006.

Mariash, H. L., Devlin, S. P., Forsström, L., Jones, R. I., and Rautio, M.: Benthic mats offer a potential subsidy to pelagic consumers in tundra pond food webs, Limnol. Oceanogr., 59, 733-744, https://doi.org/10.4319/lo.2014.59.3.0733, 2014.

Mariash, H. L., Smith, P. A., and Mallory, M.: Decadal Response of Arctic Freshwaters to Burgeoning Goose Populations, Ecosystems, 21, 1230-1243, https://doi.org/10.1007/s10021-017-0215z, 2018 .

Menden-Deuer, S. and Lessard, E. J.: Carbon to volume relationships for dinoflagellates, diatoms, and other protist plankton, Limnol. Oceanogr., 45, 569-579, https://doi.org/10.4319/lo.2000.45.3.0569, 2000.

Michelutti, N., Keatley, B. E., Brimble, S., Blais, J. M., Liu, H., Douglas, M. S. ., Mallory, M. L., Macdonald, R. W., and Smol, J. P.: Seabird-driven shifts in Arctic pond ecosystems, Proc. R. Soc. B Biol. Sci., 276, 591-596, https://doi.org/10.1098/rspb.2008.1103, 2009.

Olson, M. H., Hage, M. M., Binkley, M. D., and Binder, J. R.: Impact of migratory snow geese on nitrogen and phosphorus dynamics in a freshwater reservoir, Freshw. Biol., 50, 882-890, https://doi.org/10.1111/j.1365-2427.2005.01367.x, 2005.

Pace, M. L., Cole, J. J., and Carpenter, S. R.: Trophic Cascades and Compensation: Differential Responses of Microzooplankton in Whole-Lake Experiments, Ecol. Soc. Am., 79, 138-152, 2010.

Paerl, H. W., Gardner, W. S., Havens, K. E., Joyner, A. R., McCarthy, M. J., Newell, S. E., Qin, B., and Scott, J. T.: Mitigating cyanobacterial harmful algal blooms in aquatic ecosystems impacted by climate change and anthropogenic nutrients, Harmful Algae, 54, 213-222, https://doi.org/10.1016/j.hal.2015.09.009, 2016.

Post, D. M., Taylor, J. P., Kitchell, J. F., Olson, M. H., Schindler, D. E., and Herwig, B. R.: The Role of Migratory Waterfowl as Nutrient Vectors in a Managed Wetland, Conserv. Biol., 12, 910 920, https://doi.org/10.1111/j.1523-1739.1998.97112.x, 1998.

Przytulska, A., Bartosiewicz, M., and Vincent, W. F.: Increased risk of cyanobacterial blooms in northern high-latitude lakes through climate warming and phosphorus enrichment, Freshw. Biol., 62, 1986-1996, https://doi.org/10.1111/fwb.13043, 2017.

R Core Team: R: A Language and environment for statistical computing, $\mathrm{R}$ version 3.4.3, available at: http://www.r-project.org/ (last access: 30 November 2017), 2016.

Rautio, M., Dufresne, F., Laurion, I., Bonilla, S., Vincent, W. F., and Christoffersen, K. S.: Shallow Freshwater Ecosystems of the Circumpolar Arctic, Ecoscience, 18, 204-222, https://doi.org/10.2980/18-3-3463, 2011.

Schindler, D. W., Hecky, R. E., Findlay, D. L., Stainton, M. P., Parker, B. R., Paterson, M. J., Beaty, K. G., Lyng, M., and Kasian, S. E. M.: Eutrophication of lakes cannot be controlled by reducing nitrogen input: Results of a 37-year wholeecosystem experiment, P. Natl. Acad. Sci. USA, 105, 11254 11258, https://doi.org/10.1073/pnas.0805108105, 2008.

Taylor, J. C., Harding, W. R., and Archibald, C. G. M.: An illustrated guide to some common diatom species from South Africa, Water Research Commission, Pretoria, 2007.

Unckless, R. L. and Makarewicz, J. C.: The impact of nutrient loading from Canada Geese (Branta canadensis) on water quality, a mesocosm approach, Hydrobiologia, 586, 393-401, https://doi.org/10.1007/s10750-007-0712-8, 2007.

Utermöhl, H.: Zur Vervollkommung der quantitativen Phytoplankton-Methodik, Int. Verein Limnol., 9, 1-38, 1958.

Van Geest, G. J., Hessen, D. O., Spierenburg, P., Dahl-Hansen, G. A. P., Christensen, G., Faerovig, P. J., Brehm, M., Loonen, M. J. J. E., and Van Donk, E.: Goose-mediated nutrient enrichment and planktonic grazer control in arctic freshwater ponds, Oecologia, 153, 653-662, https://doi.org/10.1007/s00442-007-0770-7, 2007.

Vonk, J. E., Tank, S. E., Bowden, W. B., Laurion, I., Vincent, W. F., Alekseychik, P., Amyot, M., Billet, M. F., Canário, J., Cory, R. M., Deshpande, B. N., Helbig, M., Jammet, M., Karlsson, 
J., Larouche, J., MacMillan, G., Rautio, M., Walter Anthony, K. M., and Wickland, K. P.: Reviews and syntheses: Effects of permafrost thaw on Arctic aquatic ecosystems, Biogeosciences, 12, 7129-7167, https://doi.org/10.5194/bg-12-7129-2015, 2015.

Wauthy, M., Rautio, M., Christoffersen, K. S., Forsström, L., Laurion, I., Mariash, H. L., Peura, S., and Vincent, W. F.: Increasing dominance of terrigenous organic matter in circumpolar freshwaters due to permafrost thaw, Limnol. Oceanogr. Lett., 3, 186-198, https://doi.org/10.1002/lol2.10063, 2018.

Wehr, J. D., Sheath, R. G., and Kociolek, J. P.: Freshwater Algae of North America: ecology and classification, Elsevier, San Diego, USA, 2015.
Wickham, H.: ggplot2: Elegant Graphics for Data Anaylsis, Springer-Verlag, New York, 2009.

Wrona, F. J., Johansson, M., Culp, J. M., Jenkins, A., Mard, J., Myers-Smith, I. H., Prowse, T. D., Vincent, W. F., and Wookey, P. A.: Transitions in Arctic ecosystems: Ecological implications of a changing hydrological regime, J. Geophys. Res.-Biogeo., 121, 650-674, https://doi.org/10.1002/2015JG003133, 2016.

Zuur, A. F., Ieno, E. N., and Elphick, C. S.: A protocol for data exploration to avoid common statistical problems, Methods Ecol. Evol., 1, 3-14, https://doi.org/10.1111/j.2041210X.2009.00001.x, 2010. 